\title{
PENGARUH GAYA KEPEMIMPINAN KEPALA DINAS PERKEBUNAN DAN KEHUTANAN KABUPATEN TULANG BAWANG DALAM MENINGKATKAN KINERJA PEGAWAI
}

\author{
Oleh: \\ Soewito ${ }^{1}$ \\ Rika Sari ${ }^{2}$ \\ Program Studi Ilmu Administrasi Bisnis, Universitas Bandar Lampung \\ e-Mail: soewito@gmail.com
}

\begin{abstract}
ABSTRAK
Manajemen sumber daya manusia adalah perencanaan, pengorganisasian, pengarahan dan pengawasan atas pengadaan, pengembangan, pemberian kompensasi, pengintegrasian, pemeliharaan dan pemutusan hubungan kerja dengan maksud untuk membantu mencapai tujuan organisasi, individu dan masyarakat. Pada dasarnya organisasi melibatkan beberapa orang yang saling berinteraksi, di mana interaksi itu sendiri tersusun dalam suatu struktur (Moh. Agus Tulus, 1994 : 176).

Keberhasilan Dinas Perkebunan dan Kehutanan Kabupaten Tulang Bawang dalam melaksanakan kewenangan desentralisasi di bidang perkebunan dan kehutanan sangat ditentukan sekali oleh gaya kepemimpinan dalam menggerakkan pegawai-pegawai dinas sesuai dengan tugas pokok dan fungsi kerjanya. Dalam hal ini kepala dinas mempunyai langkah kerja dan pola pembinaan pegawai, yang mana setiap bulan diadakan pertemuan antara pimpinan dan seluruh staf pegawai Dinas Perkebunan dan Kehutanan Kabupaten Tulang Bawang.

Tipe penelitian ini adalah kualitatif dan kuantitatif. Penelitian kualitatif yaitu menggambarkan keadaan di lapangan berdasarkan kenyataan yang ada yang ditunjang dengan teori-teori atau literatur yang mendukung. Sedang penelitian kuantitatif yaitu penelitian berdasarkan angka-angka yang didapatkan dari hasil penyebaran angket atau kuisioner yang kemudian diolah dengan menggunakan uji statistik.

Berdasarkan hasil perhitungan statistik, maka dapat dinyatakan bahwa jika gaya kepemimpinan yang dijalankan oleh Kepala Dinas bersifat demokratis, sesuai hasil angket yang ada, seperti adanya interaksi yang baik antara atasan dan bawahan, selain itu juga pendelegasian wewenang yang jelas dari Kepala Dinas kepada bawahannya.
\end{abstract}

Kata kunci: gaya kepemimpinan, peningkatan kinerja, dinas perkebunan dan kehutanan kabupaten Tulang Bawang 


\section{PENDAHULUAN}

\section{A. Latar Belakang Masalah}

Pemimpin melalui gaya kepemimpinan yang diterapkannya dapat mempengaruhi moral dan kepuasan kerja pegawai dengan memperhatikan dan memenuhi kebutuhan pegawainya. Jika kebutuhan pegawainya terpenuhi, maka pegawai akan bekerja secara maksimal yang pada akhirnya menuju pada peningkatan prestasi kerja. Kepemimpinan adalah sesuatu yang dimiliki oleh seseorang sehingga orang tersebut mampu menggerakkan orangorang untuk melakukan perbuatan atau tindakan dengan penuh kesadaran dan keikhlasan. Kepemimpinan diperlukan untuk menyelaraskan tujuan organisasi dan tujuan individu. Selain itu kepemimpinan diharapkan akan dapat meningkatkan produktivitas kerja pegawai.

Menurut Gibson, dkk (1990 : 334), kepemimpinan adalah upaya menggunakan jenis pengaruh bukan paksaan (concoersive) untuk memotivasi orang-orang mencapai tujuannya. Lebih lanjut dijelaskan oleh Handoko (1985 : 34) bahwa dalam kepemimpinan terdiri atas berbagai macam atau cara, di mana antara cara yang satu dengan yang lain memiliki karakteristik pelaksanaan yang berbeda.

Dalam setiap organisasi formal sesuai dengan prinsip hierarki, maka pekerja yang kedudukannya lebih rendah akan mendapat pengawasan dari atasannya yang memang ditetapkan oleh peraturan untuk melakukan hal itu. Dapat dikatakan bahwa prinsip ini menggambarkan pola struktur kekuasaan atau kepemimpinan dalam setiap organisasi formal. Struktur kepemimpinan ini secara garis besar dapat dikelompokkan ke dalam tiga tingkatan kepemimpinan organisasi, yaitu:

1. Manajer Lini Pertama

Merupakan tingkatan paling rendah (lower management) dalam organisasi yang memimpin dan menguasai tenaga-tenaga operasional, seperti ketua unit, supervisor dan ketua kelompok.

2. Manajer Menengah

Merupakan pimpinan tingkat menengah (middle management) seperti seluruh posisi manajer dalam organisasi kerja.

3. Manajer Puncak

Merupakan pimpinan tingkat atas (top management) yang bertanggung jawab terhadap keseluruhan organisasi, seperti direktur utama, kuasa direksi dan dewan komisaris.

(T. Hani Handoko, 1985 : 17)

Menurut penelitian Fried E. Fiedler (dalam Wahjosumidjo, 1985 : 67), Di dalam situasi kerja ada 3 macam faktor penting yang akan menentukan gaya kepemimpinan atau perilaku kepemimpinan yang efektif, yaitu :

1. Hubungan antara pemimpin dan bawahan. Maksudnya bagaimana tingkat kualitas hubungan yang terjadi antara atasan dan bawahan.

2. Struktur tugas. Maksudnya di dalam situasi kerja yang bagaimana, apakah tugas-tugas telah disusun ke dalam suatu pola yang jelas atau sebaliknya.

3. Kewibawaan kedudukan pemimpin. Bagaimana 
kewibawaan formal pemimpin dilaksanakan terhadap bawahan.

Pembangunan daerah diselanggarakan oleh seluruh perangkat daerah yang terdiri dari sekretariat daerah, dinas daerah, lembaga teknis daerah, Satuan Polisi Pamong Praja, kecamatan dan kelurahan. Dinas Perkebunan dan Kehutanan Kabupaten Tulang Bawang termasuk unsur pelaksana pemerintah kabupaten di bidang perkebunan dan kehutanan yang dipimpin oleh seorang kepala dinas yang dalam melaksanakan tugas teknis operasional di bawah supervisi dan bertanggung jawab kepada bupati melalui sekretaris daerah.

\section{Keberhasilan Dinas Perkebunan}

dan Kehutanan Kabupaten Tulang Bawang dalam melaksanakan kewenangan desentralisasi di bidang perkebunan dan kehutanan sangat ditentukan sekali oleh gaya kepemimpinan dalam menggerakkan pegawai-pegawai dinas sesuai dengan tugas pokok dan fungsi kerjanya. Dalam hal ini kepala dinas mempunyai langkah kerja dan pola pegawai, yang mana setiap bulan diadakan pertemuan antara pimpinan dan seluruh staf pegawai Dinas Perkebunan dan kehutanan Kabupaten Tulang Bawang.

Adapun langkah kerja dan pola pembinaan pengawai yang dilakukan merupakan implementasi tugas pokok kepala dinas yang tercantum dalam SK Bupati Tulang Bawang No. 24 Tahun 2003 tentang Penjabaran Tugas Pokok dan Fungsi Dinas Perkebunan dan Kehutanan Kabupaten Tulang Bawang, yaitu:
1. Memimpin pelaksanaan tugas pegawai Dinas Perkebunan dan Kehutanan.

2. Mengawasi pelaksanaan tugas pegawai Dinas Perkebunan dan Kehutanan.

3. Mengkoordinasikan pelaksanaan tugas pegawai Dinas Perkebunan dan Kehutanan.

Objek penelitian ini adalah pegawai yang ada pada Dinas Perkebunan dan Kehutanan Kabupaten Tulang Bawang. Kemampuan pegawai menyelesaikan tugas-tugasnya mempengaruhi produktivitas kerja pegawai. Keefektifan kepemimpinan terlihat dari kehadiran pegawai, sedangkan kemampuan dilihat dari pendidikan, pengetahuan dan pengalaman dalam melakukan pekerjaan. Dengan bekal tersebut, pemimpin dapat mengarahkan kemajuan dan keterampilan dengan memberi motivasi agar pegawai dapat bekerja dengan maksimal. Turunnya semangat dan kegairahan kerja akan mengakibatkan menurunnya produktivitas kerja pada dasarnya bersumber pada ketidakpuasan pegawai terhadap prilaku kepemimpinan yang tidak efektif.

Berdasarkan uraian di atas, penulis tertarik untuk menulis dalam bentuk skripsi dengan judul "Pengaruh Gaya Kepemimpinan Kepala Dinas Perkebunan Kehutanan Kabupaten Tulang Bawang dalam Meningkatkan Kinerja Pegawai ”.

\section{B. Tujuan Penelitian}

1. Untuk mengetahui besarnya pengaruh gaya kepemimpinan dalam meningkatkan efektivitas kerja pegawai pada kantor Dinas 
Perkebunan dan Kehutanan

Kabupaten Tulang Bawang.

2. Untuk mengetahui gaya

kepemimpinan yang digunakan

oleh pimpinan di Dinas

Perkebunan dan Kehutanan

Kabupaten Tulang Bawang

dalam mencapai kinerja

pegawai.

\section{Kerangka Pemikiran}

Pada dasarnya setiap organisasi selain berupaya untuk mencapai tujuannya, baik tujuan organisasi, pegawai maupun masyarakat. Agar tujuan organisasi dapat tercapai dengan baik, perlu adanya penyelerasan antara tujuan organisasi dengan tujuan pegawai, maka diperlukan pengelolaan manajemen yang efektif untuk mengelola sumber daya manusia yang dimiliki oleh organisasi. Selanjutnya dijelaskan oleh Onong U. Effendi (1982:4) mengemukakan bahwa kepemimpinan adalah kegiatan si pemimpin untuk mengarahkan tingkah laku orang lain ke suatu tujuan tertentu.

Dalam suatu organisasi formal, setiap hal aktivitas pemimpin dalam mencapai sasaran tujuannya selalu berdasarkan kepada kebijakan dan perencanaan yang matang sehingga tidak terjadi distorsi dalam pelaksanaan penjabaran keputusan yang dibuatnya.

Fungsi pemimpin tidak hanya merencanakan langkah kerja bawahan dan target yang harus dicapai, tetapi juga pengawasan sebagai evaluasi terhadap hasil kerjanya, diantaranya:

1. Evaluasi terhadap dirinya sendiri, secara introspektif mengukur hingga di mana kemampuannya memimpin kelompok.

2. Menilai hingga di mana para bawahannya itu secara sukarela mendukung kebijakan itu. Kemudian menentukan cara-cara perbaikan terhadap hal-hal yang menyimpangdari perencanaan. Pengawasan sebagai evaluasi didasarkan kepada standar tertentu sebagai pedoman ukuran.

Kepemimpinan yang efektif diperlukan untuk menghadapi masalah yang ada di organisasi maupun untuk meningkatkan kualitas pegawai dan menjaga kelangsungan hidup organisasi. Pemimpin yang berhasil adalah mereka yang selain memiliki kemampuan pribadi tertentu, juga mampu membaca keadaan pegawai dan lingkungannya. Yang harus diketahui tentang pegawai adalah kematangan mereka sebab ada kaitan langsung antara gaya kepemimpinan yang tepat untuk diterapkan dengan tingkat kematangan pegawai agar pemimpin memperoleh ketaatan atau pengaruh yang memadai.

Salah satu cara untuk mengetahui tingkat kematangan pegawai adalah dengan melihat kemampuan dan semangat mereka dan mempertanggungjawabkan pelaksanaan tugas yang diembankan.

Menurut Fiedler (dalam Wahjosumidjo, 1985) kepemimpinan yang efektif dipengaruhi tiga faktor, yaitu hubungan antara pemimpin dengan bawahannya, struktur tugas dan kewibawaan kedudukan pemimpin.

Seorang pemimpin baru akan dapat melaksanakan pekerjaannya dengan baik jika ia menyadari akan 3 hal, yaitu: 
1. Abilitas, yaitu kemampuan atau kecakapan untuk memimpin.

2. Otoritas, yaitu kemampuan untuk melaksanakan koordinasi kerja.

3. Responsibilitas, yaitu tanggung jawab mengenai apa yang ia ambil dalam keputusan.

Jika salah satu dari ketiga hal tersebut tidak ada, maka organisasi akan kacau dan para bawahan akan saling melemparkan tanggung jawab. Pemimpin harus sadar bagaimana tindakannya sebagai pemimpin akan berpengaruh pada kerja pegawai (Fiedler dalam Wahjosumidjo, 1985 : 200).

Peningkatan keberhasilan kerja, semangat kerja, kerajinan kerja dan kedisiplinan kerja yang mengarah kepada peningkatan efektivitas kerja ditentukan juga oleh gaya kepemimpinan seseorang, maka seorang pemimpin perlu menyesuaikan gaya kepemimpinannya dengan situasi dan kondisi organisasi yang dipimpinnya.

Dari penjelasan tersebut,maka dapat digambarkan kerangka pemikiran sebagai berikut:
Gaya kepemimpinan

1. Hubungan antara pemimpin dengan bawahannya

2. Struktur organisasi

3. Partisipasi bawahan dalam pengambilan keputusan

4. Pendelegasian wewenang

Gambar 1. Bagan kerangka pemikiran

\section{Hipotesis}

Berdasarkan latar belakang, permasalahan dan kerangka pemikiran, maka hipotesis yang dikemukakan adalah gaya kepemimpinan berpengaruh positif terhadap peningkatan kinerja pegawai pada Dinas Perkebunan dan Kehutanan Kabupaten Tulang Bawang.

\section{E. Operasional Variabel}

Operasional variabel, akan dijadikan dasar pengukuran dari masingmasing variabel. Ada dua variabel yang akan penulis gunakan dalam penulisan skripsi ini, yaitu sebagai berikut :
Kinerja pegawai

1. Keberhasilan kerja

2. Semangat kerja

3. Kerajinan kerja

4. Kedisiplinan kerja

\section{Variabel $X$}

a. Secara Konsepsional Variabel gaya kepemimpinan, yaitu variabel bebas (x).

b. Secara Operasional

Gaya kepemimpinan adalah cara pemimpin untuk mempengaruhi bawahannya agar dapat dan mau menjalankan apa yang diperintahkannya.

c. Secara Indikator

Pengaruh gaya kepemimpinan yang dilakukan oleh kepala dinas akan diukur dengan indikator:

- Hubungan antara pemimpin dengan bawahannya

- Struktur organisasi 
- Partisipasi bawahan dalam pengambilan keputusan

- Pendelegasian wewenang

\section{Variabel Y}

a. Secara Konsepsional Variabelnya efektivitas kerja pegawai, yaitu variabel terikat (Y)

b. Secara Operasional

Kerja pegawai adalah memberikan pelayanan kepada masyarakat, melaksanakan tugas negara, melaksanakan tugas pemerintahan dan pembangunan.

c. Secara Indikator

Efektivitas kerja pegawai diukur dengan indikator:

- Keberhasilan kerja

- Semangat kerja

- Kerajinan kerja

- Kedisiplinan kerja

\section{TINJAUAN PUSTAKA}

\section{A. Pengertian Kepemimpinan}

Kepemimpinan mempunyai arti yang berbeda-beda menurut para pendapat yang tergantung dari bagaimana melihatnya. Menurut George R.Tery (1999:223) menyatakan bahwa kepemimpinan adalah keseluruhan kegiatan (aktivitas) untuk pengaruhi Orang lain untuk mencapai tujuan bersama, sedangkan menurut Robert Dubin (2000:124) menyatakan bahwa kepemimpinan adalah aktivitas pemegang kewenangan dan mengambil keputusan serta RaiphM.Stogdil (2001:143) menyatakan bahwa kepemimpinan adalah suatu proses mempengaruhi aktivitas kelompok dalam upaya perumusan dan pencapaian tujuan.

Dari para pendapat diatas dapat dikatakan bahwa kepemimpinan amat tergantung Pada kualitas orang yang memimpin, kesediaan orang yang dipimpin dan situasi yang tengah dihadapi. Berdasarkan pengertian diatas dapat kita simpulkan bahwa kepemimpinan merupakan kemampuan lebih yang dimiliki oleh seseorang (baik dalam organisasi atau tidak) untuk mempengaruhi orang-orang yang ada dalam lingkungannya, agar mereka bersedia bekerja untuk mencapai tujuan yang diinginkan seorang pemimpin.

Kedudukan kepemimpinan dalam suatu organisasi atau perusahaan amat penting, dalam usaha mencapai tujuan organisasi atau perusahaan itu. Berhasil atau gagalnya suatu perusahaan dalam mengemban misinya untuk mencapai tujuan, sebagian besar ditentukan oleh mutu kepemimpinan yang dimainkan oleh orang yang diserahi tugas-tugas kepemimpinan dalam organisasi yang bersangkutan. Orang yang melaksanakan atau diserahi tugas-tugas kepemimpinan disebut manajer. Dengan demikian, tugas-tugas kepemimpinan ini dapat berlaku atau ditemui di mana saja dan dalam situasi apa saja yang tidak tergantung pada struktur atau pengangkatan secara resmi. Ia dapat ditemui baik dalam organisasi yang sudah teratur rapi, maupun dalam situasi darurat atau dalam keadaan tidak normal.

Menurut Wahjusumidjo (2004:154) menyatakan bahwa dalam kepemimpinan sebenarnya terkandung makna, antara lain:

1. Kepemimpinan merupakan sesuatu yang melekat pada diri seseorang yang berupa sifat-sifat tertentu, seperti : kepribadian (personality), kemampuan 
(ability) dan kesanggupan (capability).

2. Kepemimpinan merupakan rangkaian kegiatan (activity) pemimpin yang tidak dapat dipisahkan dengan kedudukan dan perilaku pemimpin itu sendiri.

3. Kepemimpinan merupakan proses antar hubungan atau interaksi antara pemimpin, pengikut dan situasi.

Bertolak dari definisi kepemimpinan secara umum seperti diuraikan di atas, maka definisi kepemimpinan manajemen sumber daya manusia itu tiada lain dari sikap dan perilaku dalam mempengaruhi para sumber daya manusia, agar mereka mau dan bersedia bekerjasama, untuk mencapai tujuan perusahaan secara efektif dan efisien sesuai dengan yang telah ditetapkan oleh perusahaan atau organisasi.

\section{METODOLOGI PENELITIAN}

\section{A. Gambaran Umum Tempat Penelitian}

Kabupaten Tulang Bawang yang terbentuk pada tanggal 20 Maret 1997 dengan luas wilayah 7.770,84 Km2atau sekitar 22\% dari luas wilayah Propinsi Lampung merupakan daerah dengan wilayah terluas bila dibandingkan dengan kabupaten lain di Lampung. Secara administrasi Kabupaten Tulang Bawang ini terbagi menjadi 24 kecamatan dan 236 kampung definitf dan 6 kelurahan. Secara geografis Kabupaten Tulang Bawang terletak pada $3^{\circ} 45-4^{\circ} 49$ arah utara selatan dan $104^{\circ} 55-105^{\circ} 55$ arah Timur Barat. Terbagi dalam 4 unit topografi, yaitu:
1. Daerah dataran, merupakan daerah terluas yang dimanfaatkan untuk pertanian.

2. Daerah rawa di sepanjang pantai timur dengan ketinggian $\mathrm{O}-25$ $\mathrm{m}$ merupakan daerah rawa pasang surut yang dimanfaatkan untuk pertanian pasang surut.

3. Daerah river basin yaitu River Basin Tulang Bawang dan River Basin Sungai Kecil.

4. Daerah alluvial meliputi pantai sebelah timur (bagian hilir) down steem dari sungai-sungai besar yaitu Way Tulang Bawang, Way Pidada dan Way Mesuji.

Berdasarkan topografinya, Kabupaten Tulang Bawang merupakan dataran rendah $0-11$ mdpl yang dimanfaatkan untuk areal transmigrasi dan daerah rawa pasang surut di sepanjang pantai timur dengan ketinggian $0-5$ mdpl yang dimanfaatkan untuk lahan pasang surut, dengan tipe tanah podsolik merah kuning. Ketinggian tempat Kabupaten Tulang Bawang terbagi menjadi 2 wilayah yaitu $0-25 \mathrm{mdpl}$ seluas $4.192,67 \mathrm{~km}(54 \%)$ dan $25-100 \mathrm{mdpl}$ $3.578,77$ km (46 \%). Tanah di Kabupaten Tulang Bawang didominasi oleh Podsolik Merah Kuning (PMK). Jenis tanah di Kabupaten Tulang Bawang secara morfologis terbagi menjadi dua tipe yaitu jenis tanah podsolik merah kuning (lahan kering) sebanyak $40 \%$ dan tanah alluvial (lahan rawa) seluas $60 \%$. Tipe iklim di Kabupaten Tulang Bawang adalah tipe iklim $\mathrm{C}$ dengan 8 bulan basah dan 4 bulan kering, dengan rata-rata curah hujan pada tahun 2001 adalah $2.436,8 \mathrm{~mm} / \mathrm{th}$. Jumlah penduduk Kabupaten Tulang Bawang pada tahun 204 sebesar 742.100 jiwa dalam 190.722KK. Dari jumlah tersebut, yang 
terdaftar sebagai pencari kerja pada Dinas Tenaga Kerja Kabupaten Tulang Bawang sebanyak 3.128 jiwa.

\section{B. Tipe dan Metode Penelitian}

\section{Tipe Penelitian}

Tipe penelitian ini adalah kualitatif dan kuantitatif. Penelitian kualitatif yaitu menggambarkan keadaan di lapangan berdasarkan kenyataan yang ada yang ditunjang dengan teori-teori atau literatur yang mendukung. Sedang penelitian kuantitatif yaitu penelitian berdasarkan angka-angka yang didapatkan dari hasil penyebaran angket atau kuisioner yang kemudian diolah dengan menggunakan uji statistik.

a. Penelitian Kepustakaan Penelitian kepustakaan ini dilakukan dengan mempelajari literatur-literatur dan tulisantulisan ilmiah yang berkaitan dengan penelitian.

b. Penelitian Lapangan Dilakukan dengan mendatangi objek penelitian dan metode yang digunakan adalah wawancara dan penjabaran kuisioner dengan sasaran responden, yaitv pegawai yang ada pada kantor Dinas Perkebunan dan Kehutanan Kabupaten Tulang Bawang yang berjumlah 117 pegawai.

Kriteria umum untuk menentukan skor yang digunakan atas sejumlah pertanyaan yang diajukan kepada responden adalah jenjang 3 , yaitu 1,2 dan 3 untuk masing-masing alternatif jawaban. Hal ini sesuai dengan pendapat Sofian Effendi (1997) yang menyatakan bahwa peneliti harus membuat keputusan tentang skor untuk indeks yang dipergunakan dalam penulisan ini, yang diasumsikan sebagai berikut:

- $\quad$ Baik, memiliki skor 3

- $\quad$ Sedang, memiliki skor 2

- Kurang, memiliki skor 1

Total jawaban dari masing-masing responden diklasifikasikan dalam tiga kategori, yaitu tinggi, sedang dan rendah. Penentuan kategori itu berdasarkan interval yang diperoleh dari selisih antara skor tertinggi dan skor terendah dibagi tiga (Sudjana, 1997).

\section{Metode Analisis Data}

Metode analisis data yang akan digunakan di dalam pelaksanaan penelitian ini adalah:

a. Analisis Kualitatif

Yaitu menganalisa permasalahan dan mencari pemecahannya dengan menggunakan teori-teori yang berkaitan dengan gaya kepemimpinan yang tujuannya untuk meningkatkan efektivitas kerja pegawai.

b. Analisis Kuantitatif Yaitu dilaksanakan dengan menguji hipotesis yang diajukan, sesuai dengan hipotesis yang diajukan dalam penelitian ini, maka yang dipergunakan adalah metode pengujian statistik Product Moment dari Pearson dengan rumus:

$$
\begin{aligned}
& r_{x y} \\
& =\frac{N\left\{X Y-\left(\sum X\right)\left(\sum Y\right)\right\}}{\sqrt{\left\{N \cdot \sum X^{2}-\left(\sum X\right)^{2}\right\}\left\{N \cdot \sum Y^{2}-\left(\sum Y\right)^{2}\right\}}}
\end{aligned}
$$

dimana: 
$r_{x y}:$ Koefisien korelasi antara variabel $\mathrm{X}$ dan $\mathrm{y}$

$\mathrm{x} \quad$ : Hasil-hasil skor Variabel bebas

y : Hasil-hasil skor Variabel terikat

n : Banyaknya sampel

xy : Hasil perbaikan skor variabel bebas dengan variabel terikat

Y : Hasil perbaikan dan nilai Skor variabel terikat

$\mathrm{X}$ : Hasil perkalian dari nilai skor variabel bebas

(Sutrisno Hadi, 1993)

Sedangkan untuk mengetahui keeratan hubungan tersebut, maka penulis mengutip klasifikasi sebagai standar menurut Winarno Surachmad (1992) sebagai berikut :

0,000 sampai dengan $0,200=$ rendah sekali

0,201 sampai dengan $0,700=$ rendah

0,701 sampai dengan $0,900=$ tinggi

0,901 sampai dengan $1,000=$ tinggi sekali

Setelah itu untuk menguji hipotesis digunakan uji $t$, seperti yang dikemukakan oleh Sudjana (1997) yaitu:

$t_{\text {hitung }}=\frac{\sqrt[r]{n-2}}{\sqrt{1-r^{2}}}$

Dimana:

$\mathrm{t}$ : Pengujian koefisien korelasi

$\mathrm{r} \quad$ : Koefisien korelasi

n : Jumlah sampel
Dan untuk melihat apakah hipotesis yang diajukan diterima atau ditolak, maka beberapa ketentuan yang harus diperhatikan sebagai berikut:

- Tolak hipotesis nihil (Ho) dengan tingkat signifikan ditafsirkan $1 \%$ dan $5 \%$ jika ternyata $t$ hitung lebih besar dari $\mathrm{t}$ kritik pada derajat kebebasan $(\mathrm{db})$ tertentu.

- Terima Ho dengan tingkat signifikan $1 \%$ dan $5 \%$ jika ternyata t hitung lebih kecil dari t krtitik pada derajat kebebasan $(\mathrm{db})$ tertentu.

- Jika ternyata dalam analisis Ho ditolak, maka hipotesis gaya kepemimpinan diterima, yang berarti adalah ada pengaruh gaya kepemimpinan terhadap peningkatan kinerja pegawai di Dinas Perkebunan dan Kehutanan Kabupaten Tulang Bawang.

Sedangkan untuk melihat sejauh mana pengaruh gaya kepemimpinan terhadap efektivitas kerja dipergunakan rumus koefisiensi penentu, yaitu:

$\mathrm{KP}=\mathrm{r}^{2} \times 100 \%$

Pengukuran variabel digunakan teknik penskoran dari masingmasing jawaban kuisioner. Kriteria umum yang digunakan untuk penskoran adalah sebagai berikut:

- Untuk jawaban "a" diberi nilai Skor 3

- Untuk jawaban “b” diberi nilai skor 2 
- Untuk jawaban “ c" diberi nilai skor 1

Adapun cara penggolongan data tersebut adalah dengan menggunakan rumus interval, yaitu:

$I=\frac{N T-N R}{K}$

dimana:

I : Interval jawaban

NT : Nilai tertinggi

NR : Nilai terendah

$\mathrm{K}$ : Kategori

(Sutrisno Hadi, 1993)

\section{ANALISIS DATA}

\section{A. Analisis Kualitatif}

Setelah diadakan pengumpulan data dan responden penelitian yang berjumlah 30 orang padadinas Perkebunan dan Kehutanan Kabupaten Tulang Bawang berdasarkan pada penyebaran angket, maka dalam menganalisis data pada analisis kualitatif ini akan dipergunakan analisis statistik yang kemudian data-data tersebut disajikan dalam bentuk tabel tunggal dan tabel silang.

Adapun cara penggolongan data tersebut adalah dengan menggunakan rumus interval, yaitu:

$I=\frac{N T-N R}{K}$

dimana:

I : Interval jawaban

NT : Nilai tertinggi

NR : Nilai terendah
K : Kategori

(Sutrisno Hadi, 1993)

Analisis tersebut akan diuraikan pada penjelasan sebagai berikut:

Berdasarkan pada hasil pengumpulan data tentang gaya kepemimpinan, maka hasil skornya dapat digolongkan sebagai berikut:

$$
\begin{array}{rll}
- & \text { Skor tertinggi } & =30 \\
- & \text { Skor terendah } & =3 \\
- & \text { Kategori } & =3
\end{array}
$$

$I=\frac{30-13}{3}$

$I=\frac{17}{3}=5,6($ dibulatkan 6$)$

dimana pengkategoriannya adalah:

$$
\begin{aligned}
& \text { - } 10-15=\text { Kurang } \\
& \text { baik } \\
& \text { - 16-22= Cukup } \\
& \text { - 23-30= Baik }
\end{aligned}
$$

Untuk lebih jelasnya tentang gaya kepemimpinan, partisipasi bawahan, pendelegasian wewenang, keberhasilan kerja dan semangat kerja dapat dilihat pada tabel-tabel berikut:

Tabel 5. Frekuensi pola interaksi pada dinas perkebunan dan kehutanan kabupaten tulang bawang berdasarkan pada 30 orang responden penelitian.

\begin{tabular}{|l|c|c|}
\hline $\begin{array}{c}\text { Pola } \\
\text { interaksi }\end{array}$ & $\begin{array}{c}\text { Jumlah } \\
\text { (orang) }\end{array}$ & $\begin{array}{c}\text { Prosentase } \\
(\%)\end{array}$ \\
\hline Baik & 22 & 73,3 \\
\hline Cukup & 6 & 20 \\
\hline Kurang baik & 2 & 6,67 \\
\hline Jumlah & 30 & 100 \\
\hline
\end{tabular}

Sumber : hasil pengolahan data, 2007 
Berdasarkan Tabel 5 di atas Menunjukkan bahwa responden yang paling banyak menjawab baik sebanyak 22 Orang responden atau $73.3 \%$. Ini berarti gaya kepemimpinan yang dilakukan dapat dikatakan sudah berjalan baik, karena bawahannya banyak yang senang terhadap Kepala Dinas yang peduli terhadap bawahannya.

Tabel 6. Frekuensi Partisipasi Bawahan pada Dinas Perkebunan dan Kehutanan Kabupaten Tulang Bawang Berdasarkan pada 30 orang Responden Penelitian

\begin{tabular}{|l|c|c|}
\hline $\begin{array}{c}\text { Partisipasi } \\
\text { bawahan }\end{array}$ & $\begin{array}{c}\text { Jumlah } \\
\text { (orang) }\end{array}$ & $\begin{array}{c}\text { Prosentase } \\
(\%)\end{array}$ \\
\hline Baik & 16 & 53,33 \\
\hline Cukup & 8 & 26,66 \\
\hline Kurang baik & 6 & 20 \\
\hline Jumlah & 30 & 100 \\
\hline
\end{tabular}

Sumber : hasil pengolahan data, 2007

Berdasarkan Tabel 6 di atas menunjukkan bahwa responden yang paling banyak menjawab baik sebanyak 16 Orang responden atau 53,33\%. Ini berarti partisipasi bawahan yang ada di Dinas Perkebunan dan Kehutanan Kabupaten Tulang Bawang dapat dikatakan sudah berjalan baik.

Tabel 7. Frekuensi Pendelegasian Wewenang pada Dinas Perkebunan dan Kehutanan Kabupaten Tulang Bawang Berdasar pada 30 Orang Responden Penelitian

\begin{tabular}{|l|c|c|}
\hline $\begin{array}{c}\text { Pendelegasi } \\
\text { wewenang }\end{array}$ & $\begin{array}{c}\text { Jumlah } \\
\text { (orang) }\end{array}$ & $\begin{array}{c}\text { Prosentase } \\
(\%)\end{array}$ \\
\hline Baik & 20 & 66,66 \\
\hline Cukup & 5 & 16,66 \\
\hline Kurang baik & 5 & 16,66 \\
\hline Jumlah & 30 & 100 \\
\hline
\end{tabular}

Sumber : hasil pengolahan data, 2007
Berdasarkan Tabel 7 diatas menunjukkan bahwa responden yang paling banyak menjawab baik sebanyak 20 Orang responden atau $66,66 \%$, Ini berarti pendelegasian yang ada di Dinas Perkebunan dan Kehutanan Kabupaten Tulang Bawang dapat dikatakan sudah berjalan baik.

Tabel 8. Frekuensi Keberhasilan Kerja pada Dinas Perkebunan dan Kehutanan Kabupaten Tulang Bawang Berdasarkan pada 30 Orang Responden Penelitian

\begin{tabular}{|l|c|c|}
\hline $\begin{array}{c}\text { Keberhasilan } \\
\text { kerja }\end{array}$ & $\begin{array}{c}\text { Jumlah } \\
\text { (orang) }\end{array}$ & $\begin{array}{c}\text { Prosentase } \\
(\%)\end{array}$ \\
\hline Baik & 15 & 50 \\
\hline Cukup & 10 & 33,33 \\
\hline Kurang baik & 5 & 16,86 \\
\hline Jumlah & 30 & 100 \\
\hline
\end{tabular}

Sumber : hasil pengolahan data, 2007

Berdasarkan Tabel 8 di atas menyatakan bahwa responden yang memiliki keberhasilan kerja baik menjawab 15 orang (50\%), cukup 10 orang $(33,33 \%)$ dan kurang baik 5 orang $(16,66 \%)$. Hal ini berarti bahwa baru 50 $\%$ pegawai yang memiliki tingkat keberhasilan kerja dengan baik, sedangkan yang $50 \%$ masih perlu diadakan pembinaan-pembinaan untuk dapat meningkatkan hasil kerjanya.

Tabel9. Frekuensi Semangat Kerja pada Dinas Perkebunan dan Kehutanan Kabupaten Tulang Bawang Berdasarkan pada 30 orang Responden penelitian

\begin{tabular}{|l|c|c|}
\hline $\begin{array}{c}\text { Semangat } \\
\text { kerja }\end{array}$ & $\begin{array}{c}\text { Jumlah } \\
\text { (orang) }\end{array}$ & $\begin{array}{c}\text { Prosentase } \\
(\%)\end{array}$ \\
\hline Baik & 23 & 76,66 \\
\hline Cukup & 5 & 16,66 \\
\hline Kurang baik & 2 & 6,66 \\
\hline Jumlah & 30 & 100 \\
\hline
\end{tabular}

Sumber : hasil pengolahan data, 2007 
Berdasarkan tabel 9 di atas dapat diketahui bahwa sebagian besar responden yaitu sebanyak 23 orang $(76,66 \%)$ memiliki semangat kerja yang baik.

Tabel 10. Frekuensi Kerajinan Kerja pada Dinas Perkebunan dan Kehutanan Kabupaten Tulang Bawang Berdasarkan pada 30 Orang Responden Penelitian

\begin{tabular}{|l|c|c|}
\hline $\begin{array}{c}\text { Kerajinan } \\
\text { kerja }\end{array}$ & $\begin{array}{c}\text { Jumlah } \\
\text { (orang) }\end{array}$ & $\begin{array}{c}\text { Prosentase } \\
(\%)\end{array}$ \\
\hline Baik & 16 & 53,33 \\
\hline Cukup & 8 & 26,66 \\
\hline Kurang baik & 6 & 20 \\
\hline Jumlah & 30 & 100 \\
\hline
\end{tabular}

Sumber : hasil pengolahan data, 2007

Berdasarkan Tabel 10 di atas dapat diketahui bahwa kerajinan kerja responden yangbaik berjumlah 20 orang atau $66,66 \%$, cukup sebanyak 6 orang (20\%) dan kurang baik 4 orang $(13,33$ $\%)$.

Tabel 11. Frekuensi Kedisiplinan Kerja pada Dinas Perkebunan dan Kehutanan Kabupaten Tulang Bawang Berdasarkan pada 30 Orang Responden Penelitian

\begin{tabular}{|l|c|c|}
\hline $\begin{array}{c}\text { Kedisiplinan } \\
\text { kerja }\end{array}$ & $\begin{array}{c}\text { Jumlah } \\
\text { (orang) }\end{array}$ & $\begin{array}{c}\text { Prosentase } \\
(\%)\end{array}$ \\
\hline Baik & 21 & 70 \\
\hline Cukup & 6 & 20 \\
\hline Kurang baik & 3 & 10 \\
\hline Jumlah & 30 & 100 \\
\hline
\end{tabular}

Sumber : hasil pengolahan data,2007
Berdasarkan Tabel 11 di atas menunjukkan bahwa kedisiplinan kerja pegawai pada Dinas Perkebunan dan Kehutanan Kabupaten Tulang Bawang sudah baik, yaitu 21 orang (70\%), cukup 6 orang (20\%) dan kurang baik 3 orang $(10 \%)$.

Selanjutnya untuk melihat variabel efektivitas kerja dapat dilihat melalui tabel di bawah ini:

\section{Tabel 12. Frekuensi Efektivitas Kerja} pada Dinas Perkebunan dan Kehutanan Kabupaten Tulang Bawang Berdasarkan pada 30 Orang Responden Penelitian

\begin{tabular}{|l|c|c|}
\hline $\begin{array}{c}\text { Efektivitas } \\
\text { Kerja }\end{array}$ & $\begin{array}{c}\text { Jumlah } \\
\text { (orang) }\end{array}$ & $\begin{array}{c}\text { Prosentase } \\
(\%)\end{array}$ \\
\hline Baik & 17 & 56,67 \\
\hline Cukup & 4 & 13,33 \\
\hline Kurang baik & 9 & 20 \\
\hline Jumlah & 30 & 100 \\
\hline
\end{tabular}

Sumber : hasil pengolahan data, 2007

Berdasarkan Tabel 12 di atas menunjukkan bahwa responden yang paling banyak menjawab baik sebanyak 17 orang responden atau 56,67 96 . Ini berarti masih perlu adanya peningkatan kinerja yang lebih baik dari pegawai di Dinas Perkebunan dan Kehutanan Kabupaten Tulang Bawang.

Setelah secara keseluruhan, baik tabel gaya kepemimpinan maupun tabel efektivitas kerja pegawai sudah diketahui, maka selanjutnya dapat dilihat pada tabel silang sebagai berikut:

Tabel 13. Tabel Silang Antara Gaya Kepemimpinan dengan Efektivitas Kerja pegawai dinas perkebunan dan kehutanan kabupaten tulang bawang

\begin{tabular}{|c|l|c|c|c|c|c|}
\hline \multirow{2}{*}{ No } & \multirow{2}{*}{ Gaya kepemimpinan } & \multicolumn{3}{|c|}{ Efektivitas kerja pegawai } & \multicolumn{2}{c|}{ Jumlah } \\
\cline { 3 - 7 } & & Baik & Cukup baik & Kurang baik & N & Persentase (\%) \\
\hline 1. & Baik & 15 & 2 & 5 & 22 & 73,33 \\
\hline 2. & Cukup baik & 1 & 2 & 3 & 6 & 20 \\
\hline
\end{tabular}




\begin{tabular}{|c|c|c|c|c|c|}
\hline Kurang baik & 1 & 0 & 1 & 2 & 6,67 \\
\hline Jumlah & 17 & 4 & 9 & 30 & 100 \\
\hline Persentase $(\%)$ & 56,67 & 13,33 & 30 & & 100 \\
\hline
\end{tabular}

Sumber : hasil pengolahan data, 2007

Berdasarkan hasil tabel tersebut di atas, maka dapat dinyatakan bahwa jika gaya kepemimpinan yang dijalankan oleh Kepala Dinas bersifat demokratis, sesuai hasil angket yang ada, seperti adanya interaksi yang baik antara atasan dan bawahan, selain itu juga pendelegasian wewenang yang jelas dari Kepala Dinas kepada bawahannya.

Hal ini ternyata mempengaruhi efektivitas kerja, karena ternyata efektivitas kerja di Dinas Perkebunan dan Kehutanan Kabupaten Tulang Bawang dikategorikan baik seperti yang dijelaskan berikut ini:

1. Dari 22 responden yang menyatakan pola interaksi baik, 15 di antara menyatakan efektivitas kerja juga baik, 2 menyatakan cukup dan 5 orang responden yang menyatakan kurang baik. Begitu juga sebaliknya, dari 17 responden yang menyatakan efektivitas kerja pegawai baik 15 di antaranya menyatakan gaya kepemimpinan baik, 1 cukup dan 1 responden yang menyatakan kurang baik.

2. Dari 6 responden yang menyatakan gaya kepemimpinan cukup baik, 1 di antaranya menyatakan efektivitas kerja pegawai baik, 2 responden menyatakan efektivitas kerja juga cukup dan 3 responden yang menyatakan kurang baik. Begitu juga sebaliknya, dari 4 responden yang menyatakan efektivitas kerja cukup, 2 di antaranya menyatakan gaya kepemimpinan baik, 2 cukup dan tidak ada responden yang menyatakan kurang baik.

3. Dari 2 responden yang menyatakan gaya kepemimpinan kurang baik, 1 responden menyatakan efektivitas kerja pegawai baik, 1 menyatakan cukup dan tidak ada responden yang menyatakan efektivitas kerja pegawai kurang baik. Begitu juga sebaliknya, dari 9 reponden yang menyatakan efektivitas kerja pegawai kurang baik, 5 responden menyatakan gaya kepemimpinan baik, 3 menyatakan cukup dan 1 responden yang menyatakan kurang baik.

\section{B. Analisis Kuantitatif}

Untuk lebih memberikan ketajaman hasil analisis kualitatif yang tela dilakukan, maka penulis juga akan melakukan analisis kuantitatif agar hasil penelitian ini benar-benar secara ilmiah dapat dipertanggungjawabkan yang didasari oleh hasil perhitunganperhitungan dengan mempergunakan uji statistik.

Uji statistik ini akan dilakukan dengan menggunakan rumus Korelasi Product Moment agar proses mentabulasikan data ke dalam tabel untuk mengoperasionalkan rumus statistik tersebut adalah sebagai berikut: 


$$
\begin{aligned}
\mathrm{X} & =14 \\
\mathrm{Y} & =818 \\
\mathrm{X}^{2} & =19.075 \\
\mathrm{Y}^{2} & =22.636 \\
\mathrm{XY} & =20.639 \\
\mathrm{~N} & =30
\end{aligned}
$$

Data tersebut dimasukan ke dalam rumus sebagai berikut:

$r_{x y}=\frac{N\left\{X Y-\left(\sum X\right)\left(\sum Y\right)\right\}}{\sqrt{\left\{N \cdot \sum X^{2}-\left(\sum X\right)^{2}\right\}\left\{N \cdot \sum Y^{2}-\left(\sum Y\right)^{2}\right\}}}$

$r_{x y}$

$=\frac{30\{20639-(747)(818)\}}{\sqrt{\left\{30.19075-(747)^{2}\right\}\left\{30.22636-(818)^{2}\right.}}$

$r_{x y}$

$=\frac{619170-611046}{\sqrt{\{572250-558009\}\{679000-669124\}}}$

$r_{x y}=\frac{8124}{\{14241\}\{9876\}}$

$r_{x y}=\frac{8124}{140644116}$

$r_{x y}=\frac{8124}{11859}=0,685$

Dari perhitungan analisis data tersebut, diperoleh $r_{\text {hitung }}=0,685$, di mana apabila dikonsultasikan dengan $r_{\text {tabel }}$ product moment untuk $\mathrm{N}=30$, baik di taraf signifikan $5 \%=0,361$ maupun $1 \%=0,463$, ternyata $r_{\text {hitung }}$ lebih besar dari $r_{\text {tabel }}$ Atau 0,685 > 0,361 pada taraf $5 \%$ dan $0,685>0,463$ padataraf $1 \%$.

Selanjutnya untuk mengetahui keeratan hubungan tersebut, maka penulis mengkonsultasikan nilai $r_{\text {hitung }}$ dengan tabel klasifikasi sebagai standard sebagaimana terlihat di bawah ini:

Tabel 14. Daftar Klasifikasi Keeratan Hubungan gaya kepemimpinan dengan Efektivitas Kerja

\begin{tabular}{|c|c|}
\hline $\mathrm{R}$ & Klasifikasi \\
\hline Antara $0,000-0,200$ & Rendah sekali \\
\hline Antara $0,201-0,400$ & Rendah \\
\hline Antara $0,401-0,700$ & Sedang \\
\hline Antara $0,701-0,900$ & Tinggi \\
\hline Antara $0,901-1,000$ & Sangat tinggi \\
\hline
\end{tabular}

Sumber : Suharsimi Arikunto, 1991

$$
\text { Setelah nilai } r_{\text {hitung }}
$$

dikonsultasikan dengan daftar klasifikasi tersebut, ternyata nilai $r_{\text {hitung }}=0,685$ berada antara 0,401 - 0,700 dengan kriteria sedang. Dengan demikian antara gaya kepemimpinan dengan efektivitas kerja mempunyai suatu tingkat keeratan hubungan serta pengaruh yang sedang. Dan bila dilihat berdasarkan nilai prosentase maka diperoleh nilai sebesar $46,92 \%$ yang didapatkan dari hasil perhitungan $\mathrm{r} 2 \times 100 \%$.

\section{KESIMPULAN DAN SARAN}

\section{A. Kesimpulan}

Berdasarkan hasil perhitungan dan pembahasan, diperoleh kesimpulan sebagai berikut:

1. Bahwa gaya kepemimpinan yang dijalankan di Dinas Perkebunan dan Kehutanan Kabupaten Tulang Bawang termasuk dalam kategori sudah berjalan baik. Hal ini terlihat dari hasil analisis data tunggal, di mana 22 orang responden $(73,3 \%)$ menyatakan gaya kepemimpinan yang dijalankan sudah berjalan baik dan 17 orang responden $(56,67$ $\%)$ mengemukakan efektivitas kerja pegawai juga sudah berjalan baik.

2. Berdasarkan hasil analisis tabel silang diperoleh bahwa : jika 
gaya kepemimpinan dijalankan dengan baik, maka akan meningkatkan efektivitas kerja pegawai. Hal ini terbukti jika gaya kepemimpinan yang akan diikuti oleh peningkatan efektivitas kerja pegawai dan sebaliknya jika gaya kepemimpinan dijalankan kurang baik dan atau tidak baik, maka akan diikuti peningkatan efektivitas kerja para pegawai yang kurang baik juga.

3. Berdasarkan hasil perhitungan statistik diperoleh $r_{\text {hitung }}=$ 0,685, di mana hasil sersebut jika dikonsultasikan dengan nilai $r_{\text {tabel }}$ dengan $\mathrm{N}=30$ pada taraf signifikan $1 \%=0,463$ dan taraf signifikan $5 \%=0,361$. Hasil konsultasi ternyata $r_{\text {hitung }}$ lebih besar daripada $r_{\text {tabel }}$. Dengan demikian hipotesis penulis (Ha) dapat diterima dengan tingkat keeratan berada pada standard nilai korelasi antara $0,401-$ 0,700 dengan kategori interprestasi sedang $(46,92 \%)$.

\section{B. Saran}

Berdasarkan hasil analisis data dan kesimpulan di atas, maka penulis menyarankan hal-hal sebagai berikut:

1. Hubungan antara pemimpin dengan bawahan hendaknya lebih diperhatikan agar dapat terjalin dengan baik. Pemimpin harus lebih memperhatikan kepentingan pegawai dengan berusaha menciptakan hubungan yang lebih terbuka. Dengan demikian pemimpin dapat mengetahui keinginan bawahannya dan begitu pula sebaliknya sehingga efektivitas

kerja para pegawai dapat ditingkatkan.

2. Struktur tugas yang dijalankan hendaknya disusun dengan jelas, sehingga para pegawai dapat meningkatkan efektivitas kerjanya secara maksimal. Pegawai hendaknya tidak semaunya menambah beban pekerjaan di luar pekerjaan yang sudah ditetapkan. Dengan adanya struktur tugas yang jelas, maka akan tocmperiancar kinerja pegawai.

3. Kewibawaan pemimpin, selain memberikan tindakan kepada para pegawai yang tidak disiplin, hendaknya dapat memberikan penghargaan kepada para pegawai seperti memberikan reward, mengadakan promosi jabatan kepada pegawai yang dapat berprestasi dengan baik.

\section{DAFTAR PUSTAKA}

A. Fikri Jahrie, 1999, Manajemen Sumber Daya Manusia, AIMI, Jakarta,

Agus Tulus. Moh, 1994, Manajemen Sumber Daya Manusia, PT, Gramedis Pustaka Utama, Jakarta.

Arikunto. Suharsimi, 1991, Prosedur Penelitian Suatu Pendekatan Praktek, Rhineka Cipta, Jakarta.

Chung, 1988, Organizational Behavior Developing Managerial, Hopper. Publisher New York.

Effendi. Sofian, 1997, Metode Penelitian Survey, LP3S, Jakarta,

Gibson. Ivamcevich. Donnelly (Saduran Drs. Djarkasih, M.P.A), 1996, Organisasi, Erlangga, Jakarta.

Handoko. T. Hani, 1995, Manajemen, BPFE, Yogyakarta. 
Martoyo. Susilo, 1990, Manajemen Sumber Daya Manusia, BPFE, Yogyakarta.

Moenir, 1993, Manajemen Pelayanan, Tarsito, Bandung.

Prawirosentono Suyadi, 1999, Manajemen Pelayanan Umum, Rineka Cipta, Jakarta.

Siagian, 1999, Filsafat Administrasi, Gunung Agung, Jakarta.

Sianipar, 1994, Kinerja Aparatur Pemerintahan di Indonesia, Tarsito, Bandung.

Sudjana, 1997, Metode Statistik, Angkasa, Bandung,

Sutrisno Hadi, 1993, Metode Research, Tarsito, Bandung.

Wahjosumidjo, 1995, Kepemimpinan dan Motivasi, Ghalia Indonesia, Jakarta.

Wily Jhon dan Sons, 1991, Pengelolaan Sumber Daya Manusia, Bumi Aksara, Jakarta. 